\title{
IMPLEMENTATION OF ECOTOURISM IN THE MANAGEMENT OF CANDIREJO HERBAL KAMPUNG SURABAYA
}

\author{
Sucipto Sucipto ${ }^{1}$ \\ suciptosucipto@ecampus.ut.ac.id ${ }^{1}$ \\ aProgram Studi S1 Manajemen, Fakultas Ekonomi, Universitas Terbuka, Indonesia
}

\begin{abstract}
Ecotourism is a tourism activity that balances between utilization and saving (conservation). And one of the goals of the principle of ecotourism is to improve the economy of local communities. Candirejo Herbal Kampung Surabaya is one of the villages in Surabaya that promotes "green and clean" in developing it. This theme is a factor in Candirejo Herbal Village, also known as an ecotourism village. This paper focuses on applying the principles of ecotourism in Candirejo Herbal Kampung Surabaya. The purpose of this study was to determine the implementation of ecotourism and the ability of managers to implement it. For this reason, the method used to obtain information and data sources, namely interviews with management/managers, field observations to see the ecotourism implementation and using a check list to easily find out the principles of ecotourism that have been implemented. Documentation is more emphasized to the programs that have been implemented in the form of documents and to photograph something important. From the available data then a descriptive analysis is performed. Candirejo Village Administrators and the community successfully implemented the principles of ecotourism. The main key to success was that the management succeeded in realizing a clean, healthy and prosperous village community by making 7 pillars of village development and carried out cooperatively
\end{abstract}

Keyword: ecotourism, herbal village

\section{INTRODUCTION}

Ecotourism is an answer to criticism of mass tourism which is seen as damaging to resources, namely the environment and culture. In the process of its development many gave birth to new terms in the context of tourism including alternative tourism, responsible tourism, community-based tourism and ecotourism [1]. Finally, ecotourism is taken as a new paradigm to accommodate tourism that is pro-local people [2].

The presence of ecotourism to provide satisfaction, memorable experiences or new ideas or thoughts to tourists [3] because there is product differentiation. However, to realize this requires understanding and involvement of stakeholders.

At present ecotourism has become a trend in every region in Indonesia. As is the case in Kampung Candirejo Surabaya. This village has been approved as one of the environmental attractions in Surabaya.

Green living concept used to develop Candirejo Village and succeeded in becoming an alternative environmental tourism object with the nickname Kampung Eco Tourism [4]. In 2016, the UN urban conference or Preparatory Committee (Prepcom) III for UN Habitat Candirejo was chosen as one of the villages visited [5].

Candirejo is the best practice in developing green villages in the city of Surabaya. The characteristics of the Candirejo community are heterocultural population, the economic status of the community belonging to the lower middle class, and land ownership owned by the community [6].

Practices in the field, Candirejo Village has carried out the management, maintenance, security and excavation of new ecotourism areas. This is in accordance with Minister of Home Affairs Regulation No. 33/2009 concerning Guidelines for the Development of Ecotourism in Regions in the Third Part of Utilization in article 8.

Based on the above, this paper is interesting to focus on the implementation of the principles of ecotourism. To see what principles have been implemented in the context of ecotourism.

Arida looks at the implementation of the principle of ecotourism from the types of investors, government and local communities. All types are discussed in five ways, namely, first, the development process, problems and strategies. Second, the impact of ecotourism development. Third, problems and distribution of influence. Fourth, the suitability of ecotourism practices with the principle of ecotourism. And the fifth, reflection: the dynamics of 
the process of involving people.

This article is more simple, describing each principle of ecotourism (integrating the Minister of Home Affairs Regulation No. 33/2009 concerning Guidelines for the Development of Ecotourism in the Regions with Eplerwood in Fandeli based on practice in the field and understanding from managers [7].

\section{METHODS}

Data collection related to the implementation of ecotourism in Candirejo Herbal Village Tourism was carried out using the interview method (using interview guidelines focused on the heads of RTs and local communities), field observations to see the ecotourism implementation and using check lists to easily find out the principles of ecotourism that had already been implemented. To complete the primary data documentation is carried out on the village profile, activities that are included in the 7 pillars of the development of Candirejo Village. In addition, documentation was carried out to record activities and findings in the field. In addition, documentation is more emphasized to the programs that have been implemented in the form of documents and to photograph something important.

\section{RESULTS AND DISCUSSION}

\section{Process of Candirejo Herbal Village Management as Ecotourism}

In the beginning, Candirejo Herbal Village was a place for opening trash. As a result, the village becomes a slum and a den of disease (skin disease, and every day the people breathe in the air that is not fresh). For this condition, the board of RT 02 Candirejo took a stand and initiated to create a healthy environment and at the same time change the image of the environment that is clean and healthy. To realize this desire, the RT board undertook several agendas, namely, first, a formal meeting at a community meeting. to find out the aspirations of residents for village development. Second, informal communication and coordination with residents. Third, the RT board acknowledges the interests and needs of all residents with the aim of creating a clean and healthy village.

The results of the steps taken to produce several programs include:

a. RT board together with the residents who moved the TPS who were previously in front of the entrance to Kampung Candirejo near the tile market.

b. Building a hall from the results of self-help residents to facilitate coordination and gathering places.

c. Each citizen is required to plant 5 kinds of plants (toga plants, vegetable plants, fruit plants, ornamental plants and protected plants) in front of the residents 'houses with the residents' personal funds. Especially for fruit plants are fruit plants that bear fruit without the season so that it can bear fruit at any time. For this reason, the most suitable fruit plants with these criteria are starfruit and starfruit fruit plants so that these plants are the most widely planted by residents.

d. Policies and programs carried out by RT managers and residents are in line with the green and clean program. So that Candirejo Village can take part in the Green and Clean competition held by Surabaya City.

\section{Inner Model Testing (Structural Model)}

The basic concept of ecotourism is actually a balance between utilization and preservation for environmental sustainability. Based on this concept, the people of Kampung Herbal Candirejo have implemented it in the form of 7 Pillars of Candirejo Village. Based on the results of studies and observations that the 7 Pillars of the Village of Candirejo are in harmony with the principles of ecotourism:

Table 17 Pillars Of Candirejo Village

\begin{tabular}{|l|l|l|}
\hline No & 7 Pillars of Candirejo Village & \multicolumn{1}{c|}{ Activity } \\
\hline 1 & Environment & $\begin{array}{l}\text { a. Greening } \\
\text { b. Cleanliness } \\
\text { c. Health }\end{array}$ \\
\hline 2 & Economic & $\begin{array}{l}\text { a. UKM } \\
\text { b. Garbage Bank }\end{array}$ \\
\hline 3 & Nutrition & $\begin{array}{l}\text { a. Elderly Posyandu } \\
\text { b. Toddler Posyandu }\end{array}$ \\
\hline 4 & Sanitation & $\begin{array}{l}\text { a. SPAL (Saluran Pembuangan Air Limbah) Sewerage Sewer } \\
\text { b. Pandora - L (Pendaur Ulang Air Limbah) Waste Water Recycling } \\
\text { c. Healthy Latrine }\end{array}$ \\
\hline 5 & Information Technology & $\begin{array}{l}\text { a. Website } \\
\text { b. Sales of products online }\end{array}$ \\
\hline
\end{tabular}




\begin{tabular}{|l|l|l|}
\hline 6 & Education & a. Community Reading Park \\
& & b. Edu House \\
& & c. Tutoring \\
& & d. Dolanan Anak (d. Children's Games) \\
& & e. Toddler Family Development \\
& f. Foster Teen Family \\
\hline 7 & Safe and Comfortable & g. Elderly Family Development \\
& & a. CCTV \\
& & b. APAR \\
& & c. Security pos \\
& & d. Citizens Agreement \\
& & e. Emergency Point \\
& f. Kentongan \\
& g. Emergency Telephone Number \\
\hline
\end{tabular}

Source: profile of Candirejo Kampung

Based on Table 1, the 7 pillars of Candirejo's Genteng Village are as follows:

a. Environment

The first pillar focuses on creating a "green, clean and healthy village". There are three main activities of the first pillar (environment) namely, first, greening is more emphasized on maintaining food security and security with the main activities namely, nursery, care and processing of plants in the village of Candirejo. Second, cleanliness is done by way of community cooperation to clean waterways, and clean the environment. In addition, residents are also invited to manage household waste by grouping it into two parts, namely, wet waste by takakura, aerobic composter, juglangan, and glangkas. For dry waste, there is already a garbage bank and it is recycled into several products, for example drinking water for glass bottles. Third, the ultimate goal of the environmental pillar is to create a healthy environment. Activities carried out eradication of mosquito larvae nests, gymnastics and clean and healthy living behavior that is reflected, residents always wash their hands using soap, healthy homes, healthy latrines, making smoking areas and the existence of a community sink.

b. Economic

Economic activities are carried out with two models, namely household businesses from food and beverages originating from local resources (MSME). The number of MSMEs in Candirejo Village is 15 consisting of 5 MSMEs for food and 10 MSMEs for drinks. In addition, the community is empowered to manage the garbage bank. Through Karang Taruna, residents can borrow money for business development on condition that members of the garbage bank become MSME members and pay for it with garbage.

c. Nutrition

In this section there are two activities carried out by the manager, namely the Elderly Posyandu and the Toddler Posyandu. The concept that was built was "Growth and Development of Toddlers Increases, Health of the Elderly Always Maintained". The activity was carried out in collaboration with the nearest Puskesmas. Toddler Posyandu activities include weighing, immunization services, maternal and child health education, and PMT giving. As for the activities of the Posyandu Seniors, health checks, elderly gymnastics, and giving PMT.

d. Sanitation

Sanitation is more oriented to cleaning waterways. For this reason, RT managers collaborated with Surabaya pawnshops to use Pegadaian CSR funds to build a Limbang Water Recycling (PANDORA-L). In addition, the management also cooperated with the Health Department's Health Laboratory section to control water quality. This is done once a year (see Figure 1)

e. Information technology

RT managers and MSMEs utilize information technology to provide information to the wider community in cyberspace about the existence of Kampire Candirejo and to utilize it for selling products online. And now the village of Candirejo already has a website that is www.gentenggoliterasi.wordpress.com.

f. Education

Educational orientation in Candirejo village is focused on increasing community reading interest and children's interest in learning so that the board formulates several programs, namely Planetarium-themed Community Reading Gardens, Edu House, Tutoring, Child Education, Toddler Family Development, Youth Family Development, Elderly Family Development

g. Safe and comfortable

The ultimate goal of all the pillars is to provide a sense of security and comfort to all citizens. To make this happen, the management compiled a program, namely CCTV installation, APAR, Kamling Post (scheduled for guard officers every night), a citizen agreement consisting of 6 points and agreed upon by 88 residents, an emergency gathering point (this is usually used when there is a disaster such as earthquakes), kentongan (sound instrument to give signals to the public), and finally emergency telephone number 112. 




Fig. 1. Test reports

The principles of ecotourism have been implemented by RT managers together with local communities through the pillars of village village development. Of the 8 principles of ecotourism, only one principle has not been implemented, namely "preventing and overcoming the impact of tourist activities on nature and culture". The RT board has not yet made a scenario of tourist activity in the Candirejo herbal village tourist area. This is caused by several things, namely, every tourist who comes must be guided directly by the RT administrator or local guide so that all tourist activities will be monitored. In addition, the tourist area of Candirejo herbal village is not a wild nature that is prone to damage, but a township in the middle of the city by utilizing the empty space in front of the house by planting trees using pots to grow the plants.

One of the ways undertaken by the manager to overcome the density and the accumulation of two-wheeled vehicles caretaker in collaboration with the RT next to it. This is very effective in overcoming the number of vehicles at certain times. For example, when there are visits from government agencies all areas must be sterile from vehicles.

Simple to see the implementation of the principle of ecotourism can be seen in the Table 2:

Table 2 Form Of Ecotourism Implementation In Candirejo

\begin{tabular}{|l|l|l|}
\hline No & \multicolumn{1}{|c|}{ Principles of Ecotourism } & \multicolumn{1}{c|}{ Implementation } \\
\hline 1 & $\begin{array}{l}\text { Prevent and mitigate the impact of tourist } \\
\text { activities on nature and culture }\end{array}$ & $\begin{array}{l}\text { This has not been done, this village is not vulnerable to damage due to high tourist } \\
\text { arrivals. However, what needs to be done is to regulate circulation and create a scenario } \\
\text { for every tourist who comes. }\end{array}$ \\
\hline 2 & Conservation Education & $\begin{array}{l}\text { Already done entered in the first pillar. This point is very much in line with the first point } \\
\text { in the 7 } \\
\text { pillars of Candirejo Herbal Village. Since the beginning, the development has been more } \\
\text { focused on creating clean and healthy villages. }\end{array}$ \\
\hline 3 & Economic & Already carried out in the second pillar by utilizing the presence of MSMEs \\
\hline 4 & Society participation & All existing pillars are carried out by involving local communities \\
\hline 6 & Tourist satisfaction and experience & Every tourist who comes is very fascinated and attractive \\
\hline 7 & Menjaga keharmonisan dengan alam & Maintaining harmony with nature \\
\hline 8 & Accommodate local wisdom & It still doesn't exist because the community and the manager don't understand. \\
\hline
\end{tabular}

Source: Minister of Home Affairs Regulation No. 33/2009 concerning Guidelines for the Development of Ecotourism in the Regions and Eplerwood in Fandeli [7] 
The principles of ecotourism since the beginning of village development have been conceived with the aim of which is to create a clean, healthy and able to prosper the community / local residents. In realizing this, the management succeeded in convincing the community so that in the field it was carried out cooperatively.

In the future projections, Kampung Herbal Candirejo will require tourist management in terms of scheduling visits, especially for large numbers of tourists or groups. It also needs to be supported by HR capabilities in terms of homestay management, the ability to guide, and the ability to present culinary well

\section{CONCLUSION}

Candirejo Village Administrators and the community successfully implemented the principles of ecotourism. The main key to success was that the management succeeded in realizing a clean, healthy and prosperous village community by making 7 pillars of village development and carried out cooperatively namely environment, economic, nutrition, sanitation, information technology, education, safe and comfortable. 


\section{REFERENCES}

C. Fandeli. 2000. Pengusahaan Ekowisata. Yogyakarta: Fakultas Kehutanan bekerjasama dengan Unit Konservasi Sumber Daya Alam Daerah Istimewa Yogyakarta dan Pustaka Pelajar.

F.I. Warman, A. Djunaedi, D.A. Iskandar. 2018. Transformasi Kampung Hijau di Kota Surabaya (Studi Kasus di Kampung Bratang Binangun dan Kampung Genteng Candirejo). Prosiding Seminar Nasional ASPI 2018.

I. Nugroho. 2011. Ekowisata dan Pembangunan Berkelanjutan. Yogyakarta: Pustaka Pelajar. Peraturan Menteri Dalam Negeri Nomor 33 Tahun 2009 Tentang Pedoman Pengembangan Ekowisata di Daerah.

N.S. Arida, Dinamika Ekowisata Tri Ning Tri di Bali. Denpasar: Pustaka Larasan Bekerjasama dengan Fakultas Pariwisata Universitas Udayana, 2015.

S. Sucipto. 2016. Pemahaman Pemangku Kepentingan Dalam Pengelolaan Kawasan Ekowisata Gunung Api Purba Nglanggeran. Yogyakarta: Tesis Magister Kajian Pariwisata Universitas Gadjah Mada.

Tempo.co. 2016. Kampung Genteng, Wisata Eco Tourism Andalan Surabaya. https://travel.tempo.co. Diakses pada tanggal 4 Oktober 2019.

W. Winartie. 2014. Hijaunya Kampung Wisata Genteng Candirejo. http://surabaya.panduanwisata.id. Diakses pada tanggal 3 Oktober 2019. 